\title{
IMPLEMENTATION OF RESULT-BASED MANAGEMENT IN THE PROCESS OF OPERATION OF VET INSTITUTIONS
}

\author{
Oleksandra Borodiyenko', Mykhailo Bykovskyi², \\ 1 DSc in Education, Associate Professor, Head of the Foreign VET Systems Laboratory of the Institute of Vocational Education and \\ Training of NAES of Ukraine \\ http://orcid.org/0000-0001-9133-0344,e-mail: oborodienko@ukr.net \\ 2 expert in management, Ol'Miers Company \\ http://orcid.org/0000-0002-1228-5782, e-mail: Bykovskyi.Misha@gmail.com
}

\begin{abstract}
.
Relevance of the topic: the need to improve the efficiency of the management of vocational (vocational-technical) education institutions, the introduction of innovative approaches to management in order to ensure the sustainable development of the institution in the conditions of increasing competition in the educational services market.

Objective: to analyze the results of implementation of the conception of results-based management in the process of operation of VET institutions (on the example of Donetsk and Luhansk regions) and to develop recommendations for the effective implementation of such an approach.

Methods: theoretical analysis, synthesis, induction, extrapolation, questioning, self-evaluation, statistical processing of results obtained.

Results: it is found that current political, economic, socio-demographic factors significantly limit the development of VET sphere in Donetsk and Luhansk regions, which exacerbates the need to find new impulses for such development. It is determined that the priorities for interventions should, among other things, be the development of managerial capacity of the managers (principals) of VET institutions. It has been found out that results-based management should be an appropriate concept of effective management of VET institutions. Theoretical analysis of the essence of the concept of "result-oriented management" was carried out, its essential features were clarified. The specifics of the program of development of managerial competence of principals of VET institutions and the results of its implementation in Donetsk and Lugansk regions are presented. It is proved that the principles of systematic, value orientation, contextuality, self-development, multifunctionality, continuity, diversification, integration, efficiency should be taken into account in the process of development of the relevant program. It is determined that the program should include the stages of full-time training (modular training), intersession post-training support of participants, independent work (creating strategies for the development of VET institutions), evaluation (using the model the evaluation of the performance of the head of the institution by different stakeholders). Experts' survey results are presented on: relevance of the proposed management tools to the specifics of management activity of the VET institutions' managers, importance of these tools in terms of effective implementation of result-based management, readiness for implementation of this concept in management activities, existing experience of using these tools. The problems connected with the implementation of results-based management concept in the process of management of VET institutions were revealed. Recommendations for overcoming of these problems are suggested.

Conclusions. There is an urgent need to increase the managerial capacity of heads of VET institutions; it is advisable to implement a program of such development using blended learning technology; conceptual basis for content design should be result-based management; the content of the program must meet the criteria of practical orientation and adaptability. In order to avoid problems of low motivation to further utilization of competences acquired during training, it is advisable to maintain further interaction with the heads of institutions who have demonstrated high personal motivation during the training period.
\end{abstract}

Keywords: result-based management, VET institution, managerial competence, principal of VET institution, blended-learning, readiness to implementation of innovations. 
Introduction. The current period of development of vocational (vocational-technical) education in Ukraine is characterized by the implementation of some new approaches concerning: decentralization of management and improvement of the mechanism of financing the system of vocational (vocational-technical) education at the state and regional levels; increase of efficiency of functioning of regional councils of vocational (vocational-technical) education; network optimization and creation of new types of institutions, ensuring their autonomy; formation of content of vocational (vocational-technical) education on a competent basis and introduction of system of internal and external quality assurance of vocational education; modernization of the educational environment; formation of a system of professional qualifications, introduction of mechanisms to stimulate employers to participate in the educational process in VET schools; implementation of a dual form of vocational education; increasing attractiveness of vocational (vocational-technical) education. The general internal political vector of decentralization of management, including in the sphere of vocational (vocational-technical) education, necessitates the decomposition of strategic priorities and their adaptation to regional specificity. Unique features of the development of the research area in Donetsk and Lugansk regions give rise to the need for scientific reflection and practically oriented activities in the direction of its modernization, increasing the efficiency and orientation to the needs of the local labor market (National Strategy for the Development of Education in Ukraine until 2021, 2013; Sustainable Development Strategy "Ukraine - 2020", 2015; Modern Vocational Education: Draft Conceptual Framework for the Reform of Vocational Education in Ukraine, 2019).

Materials. During the last decade, various aspects of the management of educational institutions have been considered in the works of Ukrainian scientists, in particular: the general theory of management of educational institutions at different levels was developed by E. Berezniak, V. Bondar, L. Danylenko, G. Dmytrenko, G. Yelnikova, Y. Konarzhevsky, V. Lazarev, V. Maslov, N. Ostroverkhova, M. Potashnik, M. Suntsov, G. Fedorov, E. Khrykov and others; aspects of design of educational institution development became the subject of scientific research by O. Dakhin, V. Maslov, V. Monakhov, V. Pikelna, etc .; key issues of strategic management of higher education institutions were studies in the works of V.Vozniuk, B.Gershunsky, G. Dmytrenko, T. Zhornyak, L. Karamushka, K. Kolesnikova, V. Kolpakova, O. Marmazy, V. Maslov, V. Melnik, M. Navrotskaya, N. Ostroverkhova, O. Pometun, M. Potashnik, O. Rodionov, P.Tretyakov, L.Shchogolieva; aspects of project management were disclosed in the works of S. Aleynikov, S. Boushuev, M. Grinyov, L. Nozdrin, E. Matvishin, V. Morozov, L. Ponomarenko, O. Polotay, F. Freich, V. Yashchuk, etc.; aspects of management of vocational (vocational-technical) education institutions were presented in the works of N. Nychkalo, V. Radkevych, V. Svystun, L. Petrenko. Considerable attention to the research of problems of innovative management of vocational education institutions have been given in the work of foreign researchers, in particular D. Adams, D. Gamash, A. Aidli, M. Vladi, M. Barber, V. Varen, N. Burt, D. Collinson, D. Hogler, K. Holmes. However, despite existing developments, the problem of implementation of innovative approaches to the management of vocational (vocational-technical) education institutions (in particular, result-based management) has not yet been the subject of special analysis.

Thus, the purpose of this article is to analyse the results of implementation of results-based management in the process of operation of VET institutions (on example of Donetsk and Lugansk regions) and to develop recommendations for the effective implementation of this management approach.

Results and discussion. The development of the sphere of vocational (vocational-technical) education in Donetsk and Lugansk oblasts has its peculiarities, due, first of all, to the specificity of a number of factors. According to research (Baranovsky, 2019; Melnyk, 2019), they are: significant loss of resource (including economic, demographic, human, intellectual) potential caused by aggression by the Russian Federation; low rates of population birth and reproduction (which results in a significant reduction in the number of students in vocational institutions and increased competition with higher education institutions); dominance of such economic activities as agriculture, production of agricultural products, construction and reconstruction of buildings and infrastructure, coal industry, development of renewable energy, mechanical engineering and metallurgy, services; negative trends in the labour market (constant increase in outflow of labour migration, growth of the informal segment of the economy, mono-sectorial specialization of the majority of settlements, grow of phenomena of motivation for abstinence, increase in the share of persons with partial employment, high level of motivation of young people to study in other regions of the country and abroad). Therefore, at the regional level, the sphere of vocational education faces a number of challenges, including the need to organize the institution in the conditions of low attractiveness of vocational education and the need to respond promptly to the rapidly changing environment (first of all, economic environment). In such circumstances, it is important 
to increase the level of knowledge and managerial capacity of the principals of VET institutions, which will improve the competitiveness of institutions in the regional educational market, ensure the quality of educational services, and increase the demand for skilled workers in the regional labour market.

These prerequisites have identified the need to develop a program for the development of managerial competence of principals of VET institutions in Donetsk and Lugansk oblasts. The peculiarities of such a program are that the development of managerial competence of the specified category of participants was carried out in several stages using blended learning concept: full-time training (module 1), post-training support, full-time training (module 2), development and presentation by participants strategies for VET institutions, the process of comprehensive evaluation of strategies. The purpose of the training was to acquire practical skills in using the tools of operational and strategic management of VET institutions. The objectives of the training were: to familiarize the participants with the effective tools of operational, marketing and strategic management of VET institutions; acquiring participants with sustainable skills to use effective tools of operational, marketing and strategic management of the institution; to familiarize participants with modern methods of communication and motivation of the staff of the VET institution; increase of personal efficiency of participants in professional activity; encouraging the effective implementation of philosophy and culture of result-based management; motivating participants to actively apply their skills in a professional context by creating suggestions to improve the operational and strategic management of VET institutions and to use the tools learned during the training.

The conceptual basis for design of the content of management competency development was the concept of results-based management. The results of the analysis of the content of the concept of "results-based management" (Arif, Jubar and Ahsan, 2015; UNDP, 2000; UN, 2017; UN Development Team, 2011; UNICEF, 2017) make it possible to distinguish its essential features: assurance (is a management strategy which contributes to the guaranteed achievement of planned results); the complexity of the impact (recognizing the significant impact (direct or indirect) of business processes and employees involved in achieving results); objectivity (the need to make decisions based on objective information (which is based on a situational analysis) and formed a vision of the necessary changes and improvements; involves identifying the desired state, developing ways to achieve it, constant monitoring of progress towards achievement of goals, analysis of intermediate information and its correction, making the following decisions solely on the basis of analysis of previously obtained information); cyclicality (is a cyclical technology that includes the process of goal setting, planning, measurement of results and performance indicators, systematic monitoring of goals achievement, analysis and evaluation of results as a basis for future decisions); measurability (is a process of strategic planning and management based on the results of environmental research and the development of measuring instruments to achieve the objectives); management by objectives (includes cascading organizational goals to the individual lev$\mathrm{el}$, evaluating the performance of goals in different order, constant feedback to improve the results). In addition, according to the concept of developers, the content of training should meet the criteria of practical orientation (clearly meet the specifics of the sphere of vocational education and have high potential for effective application in the process of management of VET institutions) and adaptability (presenting the processes of operational and strategic management in the form of technology which included the use of effective tools and a clear algorithm for performing management functions). In accordance with the concept of result-based management, a program for the development of managerial competence of principals of VET institutions was developed (Table 1).

The following forms and methods were used for the realization of the training tasks: mini-lectures, discussions, business simulations, moderation, "critical friend" method, individual work, supervision, work in pairs, mentoring, creation of individual projects, homework, provocative dialogues. The work was organized interactively, enabling the training participants to acquire the skills to use specific tools for operational and strategic management of VET institutions. In order to consolidate the acquired knowledge and skills and increase the motivation of the training participants to apply them in a professional context, post-training support was carried out in the intersessional stage (in the form of distance counselling of participants). The purpose of the intersessional stage was to implement the acquired skills to the process of operation of VET institutions and generate strategic initiatives for institution development. At the same time, it was assumed that the participants will use the tools used during the training. The number of trainees was 52 (total number of principals of VET institutions in the studied region -67).

The majority of participants appreciated the results of the training and their own effectiveness in it. The appreciation also concerned the tools that were studied during the program. According to the participants, the proposed approach and technology of result-based management will in the future enable: to determine the 
Table 1

Program for development of managerial competence of principals of VET institutions

№ The name of the module

The name of the topic

1. Module 1. Operational management of the VET institution

- principles and methodology of result-based management;

- concept and structure of the management cycle;

- goal setting in managing the VET institution;

- key performance indicators (KPIs);

- effective planning tools;

- effective task prioritization tools;

- tools for analysing staff performance;

- concepts and principles of delegation of responsibility in the management of the VET institution;

- methods of improving the effectiveness of communication and motivation with employees

2. Module 2. Strategic management of the VET institution

- concepts and outcomes of strategic management of the VET institution;

- algorithm of strategic management;

- methods of analysis of the external environment of the VET institution;

- methods of analysis of competitive advantages in strategic planning of the

VET institution;

- methods of goal setting in strategic management;

- design of a road map of the institution's activities in strategic management;

- methods of strategic analysis;

- methods of generating strategic initiatives for the development of the VET institution's development strategy.

specific goals of VET institutions, to achieve a clear correspondence of the goal and the result; to clearly monitor and measure the outcome and analysis of the dynamics of change, determine the roadmap of the institution and performance management tools; to define specific goals, results, determine the time and resources to achieve them; to ensure speed of achievement of result; to involve the majority of employees in making the best decision; to make the institution more manageable, since strategic plans make it possible to compare the achieved results with the set goals, specified in the form of planned goals and performance indicators.

Within the intersessional stage, a survey of the participants of the training was conducted, in order to identify expert opinion on: the relevance of the proposed management tools to the specifics of the management activities of the principals of VET institutions, the importance of these tools in terms of effective implementation of result-based management, trainees' readiness for implementation of this concept, existing experience in using these tools. A 10-point scale was used in the survey; the results were differentiated by the criterion of importance as follows: 0-3 points - low level, 4-7 - medium level, 8-10 - high level. According to the results of the survey, experts differently assess the importance of certain management tools (Fig. 1): the highest rated tools were SMART, metaprogram profile (more than $50 \%$ of respondents consider these tools as highly important). Instead, a significant number of respondents rated the Pareto Principle, the Mind mapping, the Eisenhower Matrix and the ABC Analysis as less conducive to the implementation of the result-based management concept. Significant is also the differentiation of experts' opinions by the following tools: metaprogram profile, key performance indicators and working day snapshot.

The distribution of respondents according to the criterion of readiness for implementation of result-based management concept (Fig. 2) indicates a slight predominance of participants with an average level of such readiness; the proportion of those who rate their readiness as high $(36.4 \%)$ is quite high. A positive marker is that none of the participants indicated a low willingness to implement this approach. Such a result may be linked, on the one hand, to the objective state of affairs and, on the other, to the socially expected responses given by the respondents.

Monitoring of current experience (including prior experience, training experience, and intersession experience) using result-based management tools indicates a predominance among respondents who are either planning to use them soon or who already have effective experience. Also significant is the proportion of individuals who either have a negative or discreet experience in using them.

For our research is also important the opinion of the experts (trainees) regarding the possible limitations and problems associated with implementing the 


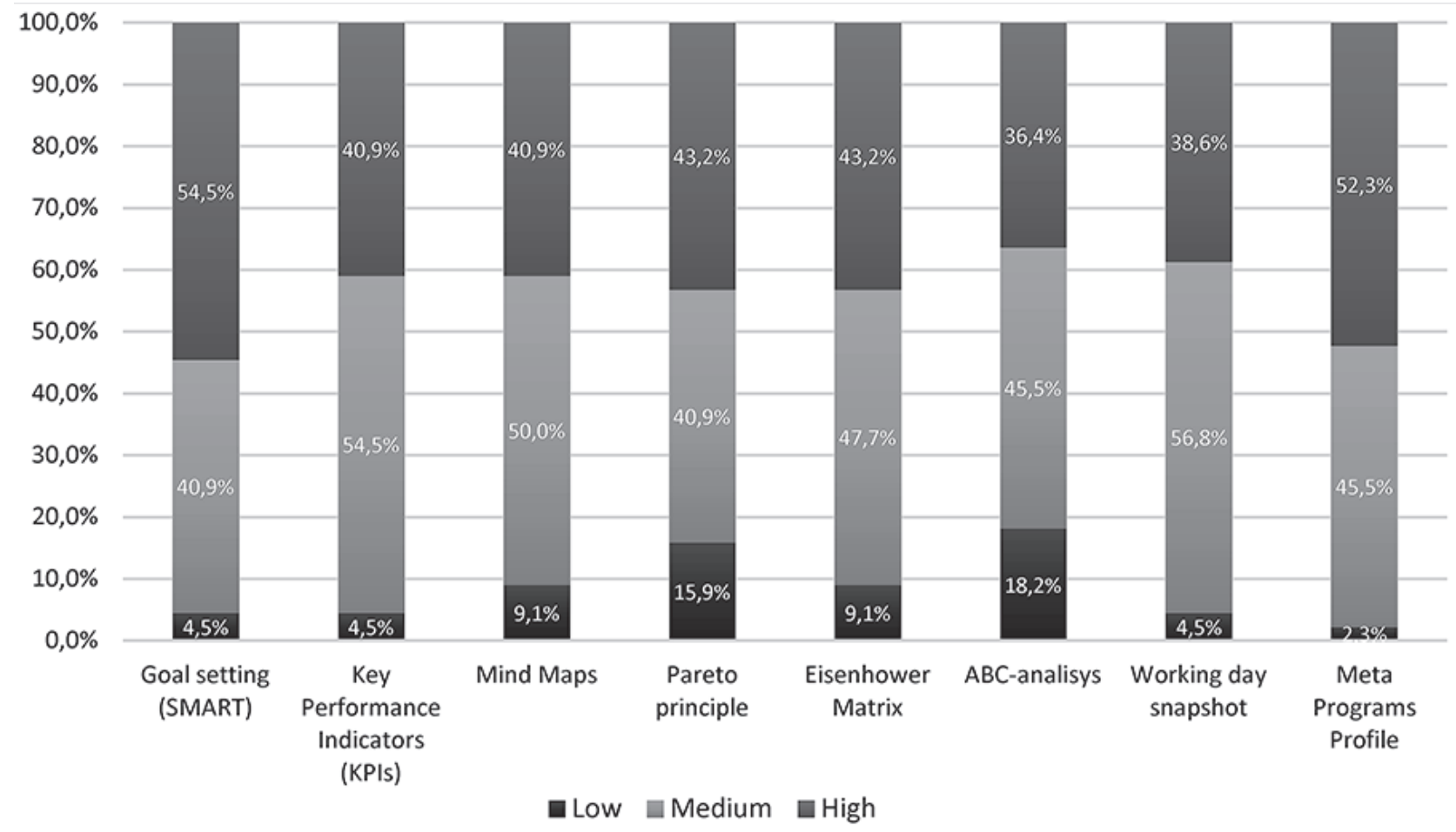

Fig. 1. Responents `assessment of management tools according with the criteria of their importance

defined management approach: lack of clear algorithms for achieving the goal; possibility of errors in actions in the process of work; inability to adjust the work before the end of the process; lack of ability to use certain tools to implement the result-based management system; focusing of risk management on operational rather than strategic aspects, reactive rather than proactive responding to risks; lack of motivation of the principal and staff for the implementation of result-based management concept; a large number of tools that a manager need to know and use at work, the duration of the process; limitation of resources to ensure systematic implementation of all tasks and activities envisaged by the strategy; non-fulfilment

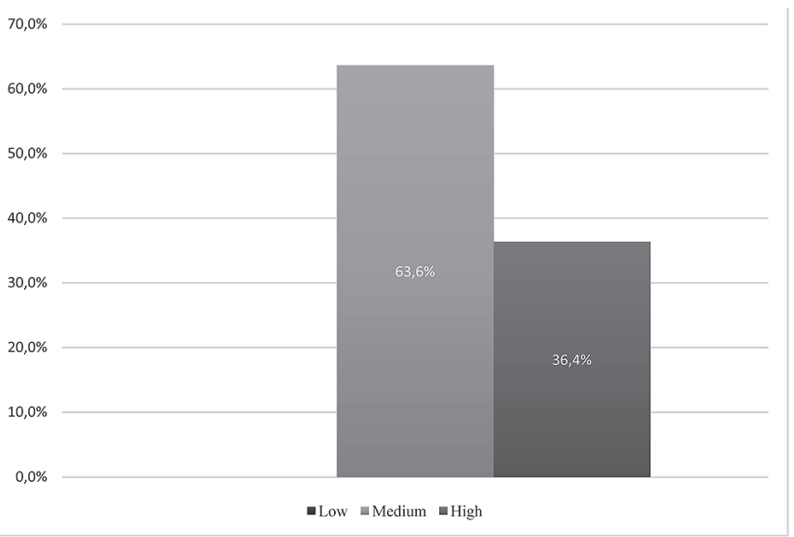

Fig. 2. Self-assessment of respondents'level of readiness for implementation of result-based management concept or partial realization of the set goals as a result of factors that do not depend on the institution; inability to anticipate all circumstances and risks at the planning stage; the determining influence of the external environment to the functioning of the institution; negative attitude of the team to the implementation of result-based management concept, their unpreparedness, lack of communication and, as a consequence, misunderstanding of management actions; lack of

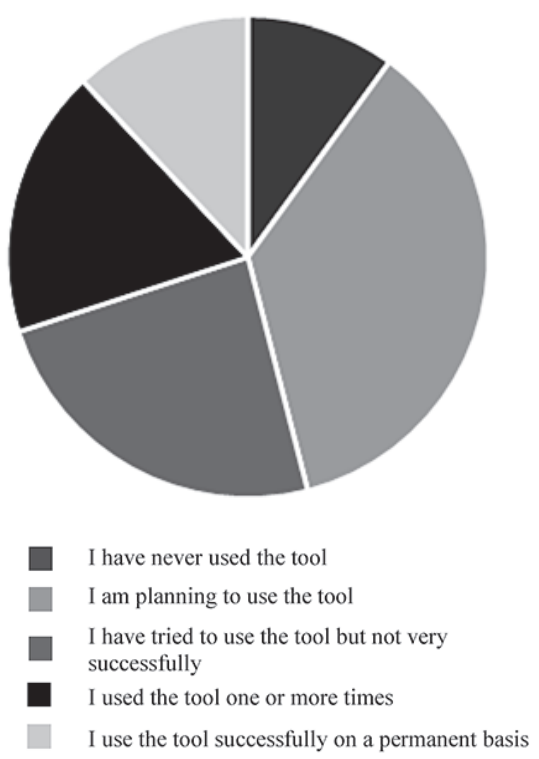

Fig. 3. Current experience in using result-based management tools 
concretization, possible blur of details and stages on the way to a certain result; complexity of taking into account unplanned issues; disorganization of employees, concentration only on the achievement of one goal, lack of independence; spending time on developing of plans and monitoring rather than working with students; misunderstanding of this methodology by employees; the need for continuous evaluation of progress towards the goal, as opposed to the process of accomplishing the tasks; the probability of deviations, mistakes in the process of reaching the goal; rejection of the new, confidence in the effectiveness of the previous management system; staffing risks (lack of staff qualifications, staff turnover, resistance to changes by staff etc.).

The results of the analysis make it possible to distinguish the following recommendations regarding the implementation of result-based management in the process of operation of VET institutions:

1. In order to enhance the managerial capacity of the principals of VET institutions, it is advisable to develop and implement a comprehensive program for the development of their managerial competence that integrates innovative approaches to the management of institutions (in particular, result-based management).

2. Developing such a program, the following principles must be taken into account: systematicity (ensuring the systemic character of pedagogical influence on trainees); value orientation (development of values and attitudes relevant to the specifics of principals' professional activity); contextuality (taking into account the peculiarities of the context of activity in the process of development of managerial competence); self-development (considering the subjects of training as self-developing ones); multifunctionality (integration of functions of development of managerial competence and ensuring purposeful implementation of the acquired knowledge and skills in professional activity); continuity (cultivating culture and values of continuous professional development); diversification (use of various forms and methods of development of managerial competence); integration (use of non-formal and informal learning technologies); efficiency (ensuring the guarantee of pedagogical impact).

3. The content of the training should meet the criteria of practical orientation (clearly meet the specifics of the sphere of vocational education and have a high potential for effective application in the process of managing of institutions) and adaptability (presenting the processes of operational and strategic management in the form of technologies that involve the use of effective tools and a clear algorithm for performing control functions).

4. In the process of implementation of the program of development of managerial competence, it is advisable to distinguish the stages of full-time study, intersession post-training support of participants, independent work, complex assessment of the quality of task performance (which will allow to acquire the cognitive basis of skills, to ensure the development of appropriate skills, to deepen the ability to use skills in working context, develop appropriate strategies for the development of VET institutions, taking into account their specific context).

5. It is advisable to form training groups in accordance with the criterion of homogeneity (by age, management experience, institution profile, etc.), which will influence the group dynamics and interest in mastering the program.

6. In order to increase the management capacity of VET institutions and the implementation of result-based management, it is also advisable to: maintain further close interaction with those trainees who have demonstrated high personal motivation during the training period; initiating a competition for the best manager of the VET institution (evaluation criteria may be those used in the process of assessment of developed strategies); further methodological support of participants (in particular creation of manuals that reveal modern tools of effective implementation of defined business processes - cooperation with stakeholders, personnel management, marketing activities, etc.); encouraging participants to use modern technologies (in particular, ICT) in the management and educational process (using the experience of European countries, where appropriate mobile applications are used for similar purposes, enabling effective operational and strategic management).

Conclusions. The conducted research makes it possible to draw the following conclusions: decentralization of management in the field of vocational (vocational-technical) education necessitates the decomposition of strategic priorities and their adaptation to regional specificity; existing political, economic, socio-demographic factors significantly limit the development of VET sphere in Donetsk and Lugansk regions; there is an urgent need to increase the managerial capacity of the principals of VET institutions, which can be realized through the development of their managerial competence; the program of such development is advisable to implement using the technology of blended learning, which involves the stages of full-time training (training on a modular basis), intersessional post-training support of participants, independent work (creating strategies for the development of VET institutions), evaluation (which models the process of evaluation of principals' performance by different stakeholders); conceptual basis for content design should be result-based management, which has meet the criteria of practical orientation and adaptability; the principles of systematicity, 
value orientation, contextuality, self-development, multifunctionality, continuity, diversification, integration, efficiency should be taken into account in the development of the relevant program. In order to avoid problems of low motivation to further use the competences acquired during training, it is advisable to maintain further close interaction with trainees who have demonstrated high personal motivation during the training period.

\section{List of references}

Барановський, М., 2019. Комплексний аналіз системи професійно-технічної освіти Донецької області. [online] Програма ООН з відновлення та розбудови миру. Доступно: <https://www.undp.org/content/dam/ukraine/docs/Donbas/ RPP/comprehensive\%20analysis\%20of\%20vocational\%20traiing\%20in\%20donetsk\%20oblast_UKR.pdf > [Дата 3вернення 10 Вересень 2019].

Бородієнко, О., 2019. Методичні матеріали для учасників тренінгу «Ефективне управління закладами професійної (професійно-технічної) освіти». [online] Програма ООН з відновлення та розбудови миру. Доступно: $<$ https:/www.ua.undp.org/content/ukraine/uk/home/library/recovery-and-peacebuilding/vocational-education-institutionsmanagement.html> [Дата звернення 10 Вересень 2019].

Бородієнко, О.В., 2015. Критерії, показники, рівні сформованості професійної компетентності керівників структурних підрозділів підприємств сфери зв'язку. Молодь і ринок, 7 (150), с. 109-115.

Бородієнко, О.В., Пуховська, Л.П., Радкевич В.О., Радкевич О.П., Леу С.О., Артемчук В.В., Базелюк Н.В. та Корчинська Н.М. 2018. Сучасні моделі професійної освіти і навчання в краӥнах Європейського Союзу: порівняльний досвід. Київ: Інститут професійно-технічної освіти НАПН України.

Верховна Рада України. Законодавство України, 2013. Про Наџіональну стратегію розвитку освіти в Украйні на період до 2021 року: Указ Президента України від 25.06.2013 № 344/2013. [online] (Останнє оновлення 06 Липень 2013) Доступно: <http://zakon3.rada.gov.ua/laws/show/344/2013>. [Дата звернення 15 Вересень 2019].

Верховна Рада України. Законодавство України, 2015. Про Стратегію сталого розвитку «Україна-2020»: Указ Президента України від 12.01.2015 № 5/2015. [online] (Останнє оновлення 12 Січень 2015) Доступно: <http:// zakon3.rada.gov.ua/laws/show/5/2015>. [Дата звернення 15 Вересень 2019].

Міністерство освіти і науки України, 2019. Сучасна професійна освіта: проект концептуальних засад реформування професійної освіти України. [online] (Останнє оновлення 16 Травень 2019) Доступно: <https://mon.gov.ua/ua/ news/mon-rozrobilo-proekt-konceptualnih-zasad-reformuvannya-profesijnoyi-osviti-ukrayini-suchasna-profesijna-osvita> [Дата звернення 15 Вересень 2019].

Мельник, С., 2019. Комплексний аналіз системи професійно-технічної освіти Луганської області. [online] Програма ООН з відновлення та розбудови миру. Доступно: $<$ https://www.undp.org/content/dam/ukraine/docs/Donbas/RPP/ analysis $\% 20$ of $\% 20$ the $\% 20$ vocational $\% 20$ education $\% 20$ and $\% 20$ training $\% 20$ system $\% 20 \mathrm{in} \% 201$ uhansk $\% 20$ oblast_UKR. pdf> [Дата звернення 10 Вересень 2019].

Радкевич, О.П., 2012а. Конфіденційність персональної інформації у соціальних мережах. Вісник Вищої ради юстииіï, 3(11), с. 215-223.

Радкевич, О.П., 2012b. Забезпечення охорони і захисту персональної інформації у Сполучених Штатах Америки та Великій Британії. Вісник Вищяӧ̈ ради юстиції, 1(9), с. 141-153.

Радкевич, О.П., 2017. Професійний розвиток викладачів і тренерів закладів професійної освіти в країнах Європейського Союзу. Науковий вісник Інституту професійно-технічної освіти НАПн Украӥни. Професійна педагогіка, 13, с. 130-139.

Maliha, A., Muhammad, J. and Ali, A., 2015. Use of Result Based Management (RBM) Framework for Monitoring Projects of Public Sector in Pakistan - A Case Study, International Journal of Innovation, Management and Technology, [online] vol. 6, n. 2. Available at: <https://www.researchgate.net/publication/318470915_Use_of_Result_Based Management_RBM_Framework_for_Monitoring_Projects_of_Public_Sector_in_Pakistan_-_A_Case_Study $>[\bar{A} c c e s s e \bar{d}$ 10 September 2019$]$.

Results Based Management Concepts and Methodology 2000. [online] UNDP Results Framework. Technical Note. Available at: $<$ http://web.undp.org/evaluation/documents/RBMConceptsMethodgyjuly2002.pdf $>$ [Accessed 10 September 2019].

Results-based management handbook. Applying RBM concepts and tools for a better urban future 2017. [online] UN-Habitat Results-Based Management Handbook. Available at: <https://urbangateway.org/system/files/documents/ urbangateway/un-habitat_rbm_handbook_complete_0.pdf $>$ [Accessed 10 September 2019].

Results-based Management Handbook. Harmonizing RBM concepts and approaches for improved development results at country level 2011. [online] United Nations Development Group. Available at: $<$ https://www.academia.edu/29138271/ RESULTS-BASED_MANAGEMENT_HANDBOOK_Harmonizing_RBM_concepts_and_approaches_for_improved_ development_results_at_country_level`’ [Accessed 10 September 2019].

Results-Based Management Handbook: Working together for Children 2017. [online] United Nations Children's Fund (UNICEF). Available at: < https://www.pndajk.gov.pk/uploadfiles/downloads/RBM_Handbook_Working_Together_ for_Children_July_2017.pdf $>$ [Accessed 10 September 2019]. 


\section{Translated \& Transliterated}

Baranovskyj, M., 2019. Kompleksnyj analiz systemy profesijno-texnichnoyi osvity Doneczkoyi oblasti [Comprehensive analysis of the system of vocational education in Donetsk region]. [online] UNDP. Available at: $<$ https://www.undp. org/content/dam/ukraine/docs/Donbas/RPP/comprehensive \%20analysis\%20of\% 20vocational\%20traiing\%20in\%20 donetsk\%20oblast_UKR.pdf $>$ [Accessed 10 September 2019], [in Ukrainian].

Borodiyenko, O., 2015. Kryteriyi, pokaznyky, rivni sformovanosti profesijnoyi kompetentnosti kerivnykiv strukturnyx pidrozdiliv pidpryyemstv sfery zvyazku [Criteria, indicators, levels of professional competence of heads`of structural divisions of telecommunication enterprises]. Youth and the Market, 7 (150), pp. 109-115, [in Ukrainian].

Borodiyenko, O., 2019. Metodychni materialy dlya uchasnykiv treningu «Efektyvne upravlinnya zakladamy profesijnoyi (profesijno-texnichnoyi) osvity». [Methodological materials for the participants of the training "Effective management of vocational (vocational) education institutions»]. [online] UNDP. Available at: $<$ https://www.ua.undp.org/content/ukraine/ uk/home/library/recovery-and-peacebuilding/vocational-education-institutions-management.html> [Accessed 10 September 2019], [in Ukrainian].

Borodiyenko, O.V., Pukhovska, L.P., Radkevych V.O., Radkevych O.P., Leu S.O., Artemchuk V.V., Bazeliuk N.V. ta Korchynska N.M., 2018. Suchasni modeli profesiinoi osvity i navchannia v krainakh Yevropeiskoho Soiuzu: porivnialnyi dosvid [Current models of vocational education and training in the countries of the European Union: comparative experience]. Kyiv: Instytut profesiino-tekhnichnoi osvity NAPN Ukrainy, [in Ukrainian].

Maliha, A., Muhammad, J. and Ali, A., 2015. Use of Result Based Management (RBM) Framework for Monitoring Projects of Public Sector in Pakistan - A Case Study, International Journal of Innovation, Management and Technology, [online] vol. 6, n. 2. Available at: <https://www.researchgate.net/publication/318470915 Use of Result Based Management RBM_Framework_for_Monitoring_Projects_of_Public_Sector_in_Pakistan_-_A_Case_Study $>[$ [Accessed $1 \overline{0}$ September 2019], [in Trello, 2019. [online] Availab̄le at: $<$ https://trello.com $>$ [Äcessed $16 \overline{\text { September }} \overline{2019}$ ], [in Ukrainian].

Verkhovna Rada Ukrainy. Zakonodavstvo Ukrainy [Verkhovna Rada of Ukraine. Legislation of Ukraine], 2013. Pro Nacionalnu strategiyu rozvytku osvity v Ukrayini na period do 2021 roku: Ukaz Prezydenta Ukrayiny vid 25.06.2013 № 344/2013 [On the National Strategy for the Development of Education in Ukraine for the Period until 2021: Presidential Decree of June 25, 2013 No. 344/2013] [online] (Ostannie onovlennia 06 Lypen 2013) Dostupno: <http://zakon3.rada. gov.ua/laws/show/344/2013> [Data zvernennia 15 Veresen 2019], [in Ukrainian].

Verkhovna Rada Ukrainy. Zakonodavstvo Ukrainy [Verkhovna Rada of Ukraine. Legislation of Ukraine], 2015. Pro Strategiyu stalogo rozvytku "Ukrayina-2020»: Ukaz Prezydenta Ukrayiny vid 12.01.2015 № 5/2015 [On the National Strategy for the Development of Education in Ukraine for the Period until 2021: Presidential Decree of June 25, 2013 No. 344/2013] [online] (Ostannie onovlennia 06 Sytchen 2015) Dostupno: <http://zakon3.rada.gov.ua/laws/show/5/2015> [Data zvernennia 15 Veresen 2019], [in Ukrainian].

Ministerstvo osvity i nauky Ukrainy, 2019. Suchasna profesijna osvita: proekt konceptualnyx zasad reformuvannya profesijnoyi osvity Ukrayiny [Modern Vocational Education: Draft Conceptual Framework for the Reform of Vocational Education in Ukraine] [online] (Ostannie onovlennia 18 Traven 2019) Dostupno: <https://mon.gov.ua/ua/news/monrozrobilo-proekt-konceptualnih-zasad-reformuvannya-profesijnoyi-osviti-ukrayini-suchasna-profesijna-osvita $>$ [Data zvernennia 15 Veresen 2019], [in Ukrainian].

Melnyk, S., 2019. Kompleksnyj analiz systemy profesijno-texnichnoyi osvity Luganskoyi oblasti [Summary of the study "Comprehensive analysis of the system of vocational education in Luhansk region»]. [online] UNDP. Available at: <https:// www.undp.org/content/dam/ukraine/docs/Donbas/RPP/analysis $\% 20$ of $\% 20$ the $\% 20$ vocational $\% 20$ education $\% 20$ and $\% 20$ training\%20system\%20in\%20luhansk\%20oblast_UKR.pdf $>$ [Accessed 10 September 2019], [in Ukrainian].

Radkevych O.P., 2012a. Konfidentsiinist personalnoi informatsii u sotsialnykh merezhakh [Privacy of personal information in social networks]. Visnyk Vyshchoi rady yustytsii [Bulletin of the High Council of Justice], 3(11), s. 215223, [in Ukrainian].

Radkevych O.P., 2012b. Zabezpechennia okhorony i zakhystu personalnoi informatsii u Spoluchenykh Shtatakh Ameryky ta Velykii Brytanii [Ensuring the safety and protection of personal information in the United States and Great Britain]. Visnyk Vyshchoi rady yustytsii [Bulletin of the High Council of Justice], 1(9), s. 141-153, [in Ukrainian].

Radkevych, O.P., 2017. Profesiinyi rozvytok vykladachiv i treneriv zakladiv profesiinoi osvity v krainakh Yevropeiskoho Soiuzu [Professional development of teachers and trainers of vocational education in the European Union]. Naukovyi visnyk Instytutu profesiino-tekhnichnoi osvity NAPN Ukrainy. Profesiina pedahohika [Scientific Herald of the Institute of vocational education and training of NAES of Ukraine. Professional Pedagogy], 13, c. 130-139, [in Ukrainian].

Maliha, A., Muhammad, J. and Ali, A., 2015. Use of Result Based Management (RBM) Framework for Monitoring Projects of Public Sector in Pakistan - A Case Study, International Journal of Innovation, Management and Technology, [online] vol. 6, n. 2. Available at: <https://www.researchgate.net/publication/318470915_Use of Result Based Management_RBM_Framework_for_Monitoring_Projects_of_Public_Sector_in_Pakistan_-_A_Case_Study $>[\bar{A} c c e s s e \bar{d}$ 10 September 2019], [in English].

Results Based Management Concepts and Methodology 2000. [online] UNDP Results Framework. Technical Note. Available at: $<$ http://web.undp.org/evaluation/documents/RBMConceptsMethodgyjuly2002.pdf $>$ [Accessed 10 September 2019], [in English].

Results-based management handbook. Applying RBM concepts and tools for a better urban future 2017. [online] UN-Habitat Results-Based Management Handbook. Available at: <https://urbangateway.org/system/files/documents/ urbangateway/un-habitat_rbm_handbook_complete_0.pdf $>$ [Accessed 10 September 2019], [in English].

Results-based Management Handbook. Harmonizing RBM concepts and approaches for improved development results at country level 2011. [online] United Nations Development Group. Available at: $<$ https://www.academia.edu/29138271/ RESULTS-BASED_MANAGEMENT_HANDBOOK_Harmonizing_RBM_concepts_and_approaches_for_improved_ development_results_at_country_level $>$ [Accessed 10 September 2019], [in English].

Results-Based Management Handbook: Working together for Children 2017. [online] United Nations Children's Fund (UNICEF). Available at: <https://www.pndajk.gov.pk/uploadfiles/downloads/RBM_Handbook_Working_Together_ for_Children_July_2017.pdf $>$ [Accessed 10 September 2019], [in English]. 


\title{
Упровадження оріснтованого на результат управління в діяльність закладів професійної (професійно-технічної) освіти
}

\author{
Олександра Бородієнко ${ }^{1}$, Михайло Биковський${ }^{2}$
}

1 доктор педагогічних наук, доцент, завідувач лабораторії зарубіжних систем професійної освіти і навчання Інституту професійно-технічної освіти НАПН України

2 експерт із питань управління персоналом, компанія “Ol’Miers”

\section{Реферат.}

Актуальність: необхідність підвищення ефективності управління закладами професійної (професійно-технічної) освіти, впровадження інноваційних підходів до управління з метою забезпечення сталого розвитку закладу в умовах підвищення конкуренції на ринку освітніх послуг.

Mema: аналіз результатів упровадження орієнтованого на результат управління (Results-based management) в діяльність закладів професійної (професійно-технічної) освіти (на прикладі Донецької і Луганської областей) та розроблення рекомендацій щодо ефективного впровадження зазначеного управлінського підходу.

Методи: теоретичний аналіз, синтез, індукція, екстраполяція, опитування, самооцінювання, статистичне оброблення результатів.

Результати. 3'ясовано, що сучасні політичні, економічні, соціально-демографічні чинники істотно обмежують розвиток сфери професійної (професійно-технічної) освіти в Донецькій і Луганській областях, що загострює необхідність пошуку нових імпульсів такого розвитку. Визначено, що пріоритетами щодо інтервенцій, крім іншого, має бути розвиток управлінської спроможності керівників закладів, зокрема розвиток їхньої управлінської компетентності. Показано, що в основі управління закладами має лежати концепція орієнтованого на результат управління (Results-based management). Здійснено теоретичний аналіз суті поняття “орієнтоване на результат управління", з'ясовано його істотні ознаки. Представлено специфіку програми розвитку управлінської компетентності керівників закладів професійної (професійно-технічної) освіти в Донецькій і Луганській областях та результати їі реалізації. Доведено, що в процесі розроблення відповідної програми варто брати до уваги принципи системності, ціннісної зорієнтованості, контекстності, саморозвитку, поліфункціональності, безперервності, диверсифікації, інтеграції, результативності. Визначено, що програмою мають передбачатись етапи очного навчання (тренінги на модульній основі), міжсесійного посттренінгового супроводу учасників, самостійної роботи (створення стратегій розвитку закладів), оцінювання (моделює оцінювання результативності діяльності керівника закладу різними стейкхолдерами). Представлено результати опитування експертів щодо: релевантності запропонованих управлінських інструментів специфіці управлінської діяльності керівників закладів, важливості зазначених інструментів, з точки зору ефективної реалізації орієнтованого на результат управління, готовності до впровадження цієї концепції в управлінську діяльність, наявного досвіду використання запропонованих інструментів. Виявлено проблеми, пов'язані з упровадженням орієнтованого на результат управління в діяльність закладів професійної (професійно-технічної) освіти. Запропоновано рекомендації щодо подолання зазначених проблем.

Висновки. Гострою $є$ необхідність підвищення управлінської спроможності керівників закладів професійної (професійно-технічної) освіти; програму такого розвитку доцільно реалізувати за технологією змішаного навчання; концептуальною основою виокремлення змісту має стати орієнтоване на результат управління; зміст програми має відповідати критеріям практичної зорієнтованості та технологічності. Для уникнення проблем низької вмотивованості до подальшого використання набутих під час навчання компетентностей доцільним є підтримання подальшої взаємодії з керівниками закладів, які продемонстрували високу особисту вмотивованість упродовж періоду навчання.

Ключові слова: орієнтоване на результат управління, заклад професійної (професійно-технічної) освіти, управлінська компетентність, керівник закладу, змішане навчання, готовність до впровадження інновацій. 